\title{
Detection of microsatellite instability but not truncating $A P C$ mutations in gastric adenocarcinomas in Brazilian patients
}

\author{
Roberta A.U. Bevilacqua, Cassandra M. Corvello, Ana Paula Duarte and Andrew J.G. Simpson
}

\begin{abstract}
A crucial role for the adenomatous polyposis colonic $(A P C)$ gene in colorectal carcinogenesis has been conclusively established, but, the role of $A P C$ in gastric tumors remains controversial. $A P C$ mutations have been detected at a relatively high frequency in gastric tumors of Japanese patients, yet such mutations have been reported to be extremely rare in British patients and patients from north-central-Italy. We here report the analysis of 40 primary sporadic gastric adenocarcinomas and 35 primary sporadic colon adenocarcinomas (from patients resident in São Paulo, Brazil), for mutations in the $A P C$ gene between codons 686 and 1693 using the protein truncation test. Although 19 truncating mutations were detected in 35 colon adenocarcinomas (54.2\%) none were found in any of the gastric adenocarcinomas. As an internal control the tumor samples were also evaluated for microsatellite alterations, which are also common features of both tumor types. Microsatellite instability was present in 1 colon and 7 gastric tumor samples. This suggests that in relation to APC mutations gastric adenocarcinomas from Brazilian patients are similar to those that occur in Europe, and support a fundamental difference both between gastric carcinomas that occur in different geographical regions and between the molecular etiology of gastric and colorectal adenocarcinomas occurring in São Paulo, Brazil.
\end{abstract}

\section{INTRODUCTION}

Gastric cancer is one of the most frequent cancers worldwide, especially in Japan, China, South America, Eastern Europe and north-central Italy. There are more than 20,000 new cancer cases per year in Brazil, with a 5-year survival rate $<10 \%$ (INCA, 1998). Although environmental agents such as tobacco, alcohol, highly salted food and $H$. pylori infection have been identified as risk factors in the development of gastric cancer (Fuchs and Mayer, 1995), the molecular mechanisms of gastric carcinogenesis remain relatively unexplored.

A number of genetic abnormalities have been identified in gastric cancers, including loss of heterozygosity $(\mathrm{LOH})$ at various loci, mutations in protooncogenes and tumor suppressor genes, in addition to abnormal expression of growth factors, hormones and cytokines (Tahara, 1993). However, all these abnormalities individually exhibit frequencies of less than $50 \%$ in gastric tumors, and are very variable depending on the number and origin of the samples analyzed. The relevance and role of each of these changes in gastric tumorigenesis remain to be determined, but a more precise and detailed genetic model of tumor progression has been established for colorectal cancer (Vogelstein and Kinzler, 1993). Since gastric and colon tumors share some common genetic lesions (Uchino et al., 1993) it is germane to inquire to what extent the two major tumor types of the gastrointestinal tract may be treated as molecularly related tumors, thus permitting a more rapid advance in our understanding of the relatively less studied gastric tumors.

Frequent and fundamental lesions in colorectal tumors are mutations in the adenomatous polyposis coli gene (APC), which was first isolated in 1991 and demonstrated to be mutated both in the germline of patients with inherited familial adenomatous polyposis (FAP) as well as in approximately $50 \%$ of sporadic forms of colorectal tumors (Groden et al., 1991, Kinzler et al., 1991; Miyoshi et al., 1992a; Powel et al., 1992; Uchino et al., 1993). The majority of $A P C$ mutations identified to date are truncating in nature (Horii et al., 1992; Miyoshi et al., 1992a,b; Nakatsuru et al., 1992). In FAP patients the mutations are distributed evenly along the 15 exons of the gene, while in the sporadic cases the mutations are highly concentrated between codons 1280 and 1500 encoded in exon 15 (Miyaki et al., 1994).

Several somatic truncating and missense mutations of the $A P C$ gene have been described in gastric cancers and adenomas from Japanese patients (Horii et al., 1992, Nakatsuru et al., 1992, 1993; Tamura et al., 1994), but other investigators have not been able to detect mutations in the $A P C$ gene in similar studies of gastric cancer in other geographical regions (Ogasawara et al., 1994; Maesawa et al., 1995). Thus, further studies of $A P C$ gene mutations in gastric cancer are required, especially in non-Japanese patients, in an attempt to determine their relevance to gastric tumor development. In the present study we report the results of the analysis of gastric tumors from Brazilian patients for truncating mutations in the $A P C$ gene. 
Microsatellite instability (MSI) is a characteristic feature of tumors from patients affected with hereditary nonpolyposis colorectal carcinoma (Aaltonen et al., 1993; Liu et al., 1996). These alterations have also been found in a variety of sporadic tumors (Eshleman and Markowitz, 1995) including gastric carcinomas, where it has been reported at frequencies of between 15\% (Strickler et al., 1994) to $33 \%$ (Chong et al., 1994) in tumors from diverse geographic areas. In addition, we have used MSI detection as a control of the quality of gastric tumor samples in terms of their capacity to permit detection of clonal molecular alterations.

\section{MATERIAL AND METHODS}

\section{Samples and DNA extraction}

Forty primary gastric tumors and thirty-five primary colon tumors together with corresponding normal mucosa were obtained from the Hospital do Câncer, São Paulo. The samples were immediately frozen in liquid nitrogen after surgical resection and stored at $-70^{\circ} \mathrm{C}$ until use. DNA was extracted by a phenol chloroform procedure. Hematoxylin- and eosin-stained sections were used to categorize the tumors according to the classifications of Lauren.

Gastric adenocarcinoma specimens were obtained from patients admitted to the Hospital do Câncer, São Paulo, Brazil. These tumors included all TNM stages, although $92.5 \%$ were classified as stage II or higher, and $7.5 \%$ classified as stages Ia and Ib. Most tumors had a distal location (body and antrum) but 13/40 (32.5\%) were of the intestinal type and $27 / 40(67.5 \%)$ of the diffuse type. The five-year survival rate of these patients is $32.5 \%$. The colorectal tumors were all adenocarcinomas, also obtained from patients admitted to the Hospital do Câncer.

\section{Protein truncating test for the $A P C$ gene}

Codons 686-1693 of the $A P C$ gene were analyzed for mutations using the in vitro synthesis protein (IVSP) assay exactly as previously described (Powell et al., 1992; Van der Luijt et al., 1994). In brief, two overlapping fragments of exon 15 of the $A P C$ gene, one encompassing codons 686 to 1217 , and the other, codons 1099 to 1693 , were amplified from the gastric and colorectal tumor samples using the polymerase chain reaction (PCR). The PCR reactions were undertaken in a $20-\mu \mathrm{l}$ reaction volume containing: 50 ng of genomic DNA, 20 pmol of each primer (for codons 686 to $1217: 5$ '-GCTAATACGACTCACTATAGGAACAG ACCACCATGGTGGCTGCAGCTTCA-3' and 5'-GCAGA GTGTGTGCTACTAAGA-3', and for codons 1099 to 1693: 5'-GATCCTAATACGACTCACTATAGGGAGACCACC ATGGTTTCTCCATACAGGTCACGG-3' and 5'-GGAGGAT CCTGTAGGAATCCTATCTCG-3'), $200 \mu \mathrm{M}$ of each dNTP, PCR buffer containing $1.5 \mathrm{mM} \mathrm{MgCl}_{2}$ and $1 \mathrm{U}$ of taq polymerase. The amplification program consisted of $5 \mathrm{~min}$ at $95^{\circ} \mathrm{C}$, followed by 35 cycles of $1 \mathrm{~min}$ at $95^{\circ} \mathrm{C}, 1 \mathrm{~min}$ at $58^{\circ} \mathrm{C}$ and $4 \mathrm{~min}$ at $72^{\circ} \mathrm{C}$, and a final extension for $7 \mathrm{~min}$ at $72^{\circ} \mathrm{C}$. Successful amplification was demonstrated by electrophoretic analysis of the PCR products on $8 \%$ polyacrylamide gels and silver staining (Sanguinetti et al., 1994). The PCR products were used directly as templates for the IVSP assay, which consisted of a coupled in vitro transcription and translation reaction capable of detecting translation-terminating mutations. The reaction was perfomed using the TnT kit (Promega) together with 40 $\mu \mathrm{Ci}$ of $\left[{ }^{35} \mathrm{~S}\right]$-methionine (ICN Biochemicals). In this process synthesis is directed from the nucleotides included at the 5'end of each forward amplification primer which contains a T7-promoter and an eukaryotic translation initiation sequence. Samples were diluted in sample buffer and denatured before loading onto SDS-PAGE gels. Proteins were visualized by autoradiography.

\section{Microsatellite analysis}

Microsatellite instability was detected using oligonucleotide primer pairs for microsatellite regions containing dinucleotide repeats (D2S119, D2S123, D2S134, D2S136, D2S147, D2S177, D10S89, D12S43, D13S71 and D17S250). PCR was carried out in the presence of $0.1 \mu \mathrm{Ci}\left[\alpha-{ }^{32} \mathrm{P}\right]-\mathrm{dCTP}$. The amplification program consisted of 35 cycles comprising $1 \mathrm{~min}$ at $95^{\circ}, 1 \mathrm{~min}$ at $56^{\circ}$ and 1 min at $72^{\circ} \mathrm{C}$. The PCR products were electrophoresed on denaturing $6 \%$ polyacrylamide DNA sequencing gels and visualized by autoradiography.

\section{RESULTS}

\section{$A P C$ truncating mutations}

We searched for truncating $A P C$ mutations between codons 686 and 1693 using the IVSP assay, which detects two-thirds of the $A P C$ mutations previously identified in colorectal tumors. In the samples tested truncating $A P C$ mutations were identified in 19 of the 35 colon tumors, examples of which are shown in Figure 1A, where a truncated peptide was detected in tumors $1,2,5$, and 13, but truncated peptides were not detected in any of the gastric tumors (Figure 1B).

\section{Microsatellite instability}

Microsatellite instability in at least one locus was identified in 10/40 (25.0\%) of the gastric tumors. Of these ten, three exhibited only single locus alterations and were not considered to be MSI+. Seven gastric tumors showed alterations at two or more of the loci tested and were considered MSI+ 7/40 (17.5\%) (Table I). Only one tumor, T13, showed LOH in D2S136 and D10S89 regions. These data clearly demonstrate that the lack of $A P C$ mutations is a meaningful negative finding. 
A

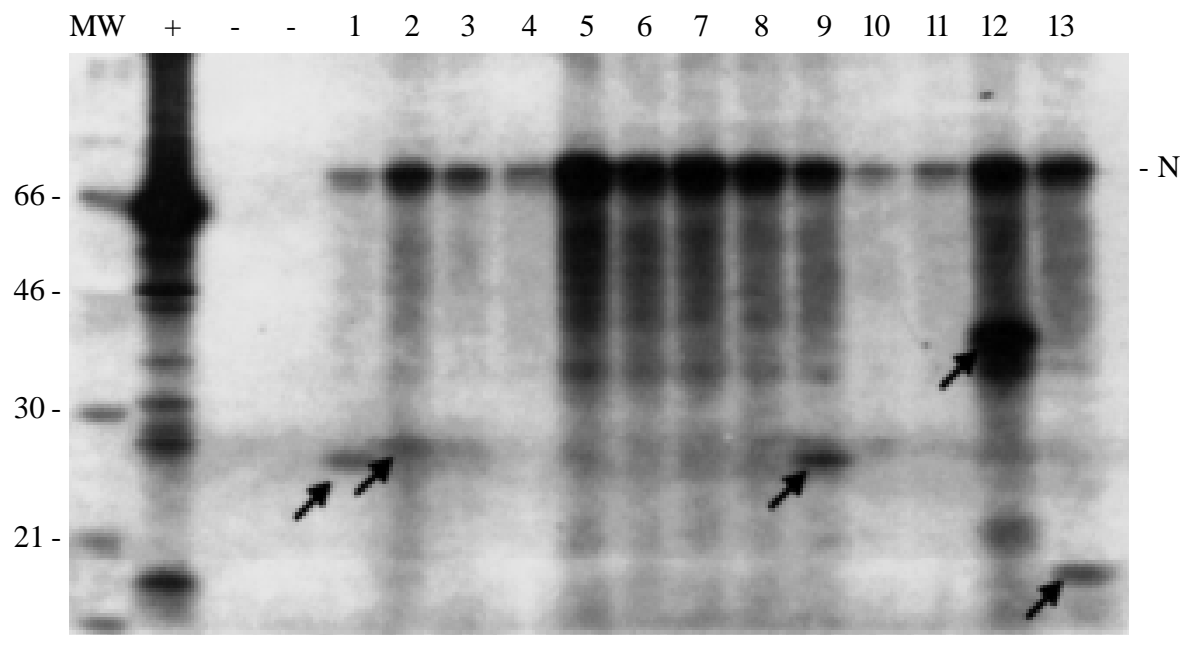

B

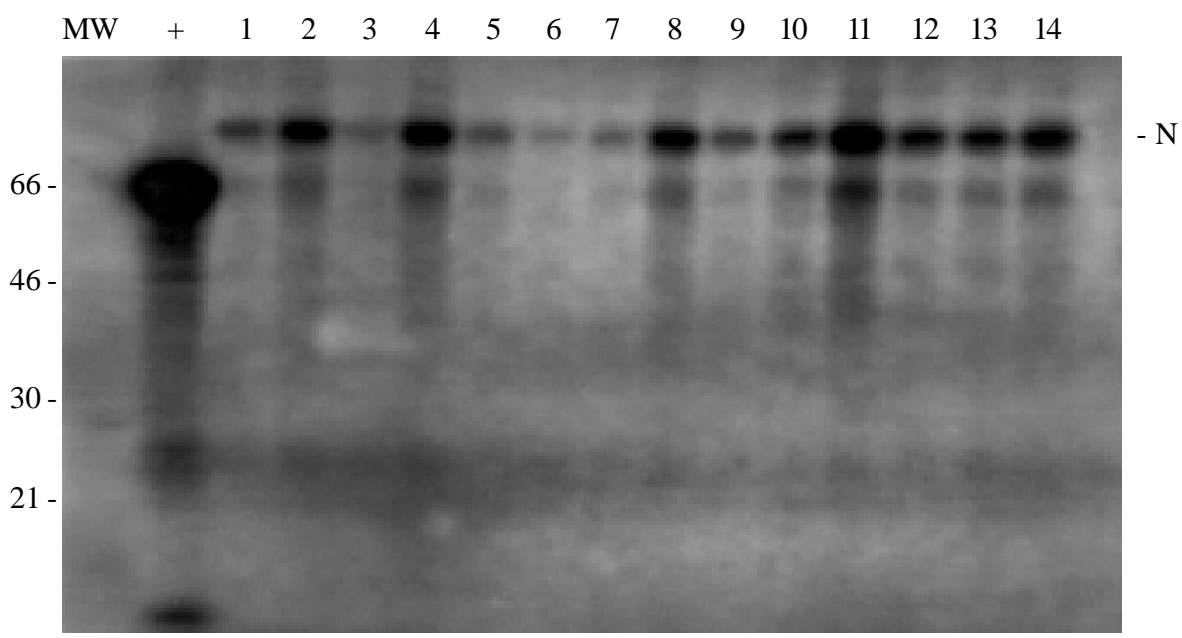

Figure 1 - Two overlapping segments of APC, encompassing codons 686 to 1217 and codons 1099 to 1693, were analyzed in 35 colon adenocarcinomas and 39 gastric adenocarcinomas. The figure shows the result of 13 and 14 representative samples of each tumor type obtained with the codon 1099 to 1693 fragment. A. Representative results obtained using DNA from colon tumors (1 to 13). Truncated protein products are indicated by the arrowheads. $\mathrm{N}$ indicates the position of the full length product. + and - are positive (luciferase) and negative (no DNA) controls, respectively. The numbers on the left are the size of the molecular weight (MW) markers. B. Representative results obtained using DNA from gastric tumors (1 to 14). $\mathrm{N}$ indicates the position of the full length product. + is the positive (luciferase) control. The numbers on the left are the size of the molecular weight markers (MW).

Table I - MSI in primary gastric tumors.

\begin{tabular}{|ccccccccccc|}
\hline Patient & D2S119 & D2S123 & D2S134 & D2S136 & D2S147 & D2S177 & D10S89 & D12S43 & D13S71 & D17S250 \\
\hline 4 & + & + & + & - & + & + & - & + & + & + \\
6 & - & - & - & - & - & - & - & + & - & + \\
11 & - & - & - & - & - & - & - & + & - & - \\
12 & - & - & + & - & - & - & - & - & - & - \\
13 & + & + & + & LOH & + & + & LOH & - & + & + \\
19 & - & + & - & + & - & + & - & + & - & + \\
20 & - & - & - & - & - & + & - & - & - & - \\
21 & + & - & - & + & + & - & - & - & - & - \\
25 & - & - & + & - & - & + & + & - & - & + \\
26 & - & + & + & - & - & + & + & + & + & + \\
\hline
\end{tabular}

+ , Altered alleles detected; -, altered alleles not detected; $\mathrm{LOH}$, loss of heterozygosity detected. 


\section{DISCUSSION}

Little is known about which genetic alterations are significant in gastric cancer and, in contrast to colorectal cancer, no clear sequence of genetic changes has been elucidated. The only gene consistently demonstrated to be frequently altered in gastric carcinomas is $p 53$ (Uchino et al., 1993; Strickler et al., 1994). Other genetic changes that have been reported include $\mathrm{LOH}$ on chromosomes $1 \mathrm{q}$, 5q, 17p (Sano et al., 1991), 7p (Kuniyasu et al., 1994) and 18q (Uchino et al., 1992), amplification of the erbB-2 oncogene (Park et al., 1989), alterations of E-cadherin, microsatellite instability and abnormalities of growth factor and growth factor receptors and TRP-MET rearrangement (Tahara, 1993). Our data, added to those of Ogasawara et al., 1994 and Maesawa et al., 1995, show that the possible role of $A P C$ mutations in gastric cancer needs to be carefully evaluated. Significant allelic loss on chromosome 5q loci at or near the $A P C$ gene has been reported in gastric adenocarcinomas, varying from 20 to $86 \%$ depending on sample preparation and methods of analysis (Sano et al., 1991; Tamura et al., 1993; Rhyu et al., 1994a). In addition, several somatic truncating and missense mutations of $A P C$ have been recently noted on partial single stranded conformational polymorphism or ribonuclease protection screening analysis of gastric cancers and adenomas from Japanese patients (Horii et al., 1992; Nakatsuru et al., 1992; Tamura et al., 1994), but these data have not been reproduced in patients from Brazil, Great Britain or Italy. This suggests that there may be an alternative tumor suppressor gene close to APC involved in gastric cancer (Powell et al., 1996; Sud et al., 1996).

We cannot exclude the possibility that our samples could have mutations outside the domain explored or missense mutations, which would not be identified by our assay. This would imply, however, a different mechanism of $A P C$ involvement in gastric and colorectal tumorigenesis (given the clear preponderance of truncating mutations in exon 15 in the latter) supporting the notion of dichotomy between the two tumor types. The data obtained with the colorectal tumors agree with the findings of others, thus serving as a good positive control for the assay (Miyoshi $e t$ al., 1992b; Powell et al., 1992).

Although we have used microsatellite instability here principally as a control the findings are worthy of comment. We found microsatellite instability in 7 of 40 human gastric cancers $(17.5 \%)$. Although our results are similar to the studies of Mironov et al., 1994, Chong et al., 1994 and Rhyu et al., 1994b, we did not find an association between MSI and clinicopathological features, such as age, sex, size, histological differentiation, depth of invasion, lymph node metastasis or survival rate. Nevertheless, our data show that MSI at a high frequency is a constant feature of gastric tumors irrespective of geographic (and hence environmental) considerations.

In summary, although we detected 7 of $40 \%$ (17.5\%) gastric samples with microsatellite instability, our results indicate that genetic alterations of the $A P C$ gene commonly present in colorectal tumors are infrequent in sporadic gastric adenocarcinomas from Brazilian patients, adding to the evidence that colon and gastric cancers do not share the same carcinogenic pathway, at least in British, north Italian and Brazilian patients.

\section{ACKNOWLEDGMENTS}

The tumor samples were obtained from the Hospital do Câncer, São Paulo, Brazil. Research supported in part by the Fundação de Amparo à Pesquisa do Estado de São Paulo and the Ludwig Institute for Cancer Research. Publication supported by FAPESP.

\section{RESUMO}

Um papel crucial para o gene da polipose cólica adenomatosa $(A P C)$ na carcinogênese colo-retal já está estabelecido, mas sua participação nos tumores gástricos permanece controversa. Mutações no $A P C$ foram detectadas com uma freqüência relativamente alta em tumores gástricos em pacientes japoneses, mas tais mutações foram relatadas como sendo muito raras em britânicos e em pacientes da região norte-central da Itália. Nós relatamos aqui a análise de 40 adenocarcinomas gástricos esporádicos primários e 35 adenocarcinomas cólicos esporádicos primários (de pacientes residentes em São Paulo, Brasil), quanto a mutações no gene $A P C$ entre os códons 686 e 1693, usando o teste da proteína truncada (PTT). Embora 19 mutações que levem a formação de uma proteína truncada tenham sido detectadas em 35 adenocarcinomas do colo (54,2\%), não se encontrou nenhuma nos adenocarcinomas gástricos. Como um controle interno, as amostras tumorais foram também avaliadas quanto à presença de alterações de microssatélites, que também são características comuns a ambos os tipos de tumores. Encontrou-se instabilidade de microssatélites em uma amostra de tumor cólico e em 7 de tumores gástricos. Este fato sugere que, no que diz respeito a mutações do $A P C$, os adenocarcinomas gástricos de pacientes brasileiros são semelhantes aos que ocorrem na Europa, e confirmam a diferença fundamental que existe tanto entre os carcinomas gástricos que ocorrem em diferentes regiões geográficas como entre a etiologia molecular de adenocarcinomas gástricos e colo-retais que ocorrem em São Paulo, Brasil.

\section{REFERENCES}

Aaltonen, L.A., Peltomaki, P., Leach, F.S., Sistonen, P., Pylkkanen, L., Mecklin, J.P., Jarvinen, H., Powell, S.M., Jen, J. and Hamilton, S.R. (1993). Clues to the pathogenesis of familial colorectal cancer [see comments]. Science 260: 812-816.

Chong, J.M., Fukayama, M., Hayashi, Y., Takizawa, T., Koike, M., Konishi, M., Kikuchi-Yanoshita, R. and Miyaki, M. (1994). Microsatellite instability in the progression of gastric carcinoma. Cancer Res. 54: 45954597.

Eshleman, J.R. and Markowitz, S.D. (1995). Microsatellite instability and sporadic neoplasms. Curr. Opin. Oncol. 7: 83-89.

Fuchs, C.S. and Mayer, R.J. (1995). Gastric carcinoma [see comments]. N. Engl. J. Med. 333: 32-41.

Groden, J., Thliveris, A., Samowitz, W., Carlson, M., Gerbert, L., Alberttsen, H., Joslyn, G., Stevens, J., Spirio, L. and Robertson, M. (1991). Identification and characterization of the familial adenomatous polyposis coli 
gene. Cell 66: 589-600

Horii, A., Nakatsuru, S., Miyoshi, Y., Ichii, S., Nagase, H., Kato, Y., Yanagisawa, A. and Nakamura, Y. (1992). The APC gene, responsible for familial adenomatous polyposis, is mutated in human gastric cancer Cancer Res. 52: 3231-3233.

Kinzler, K.W., Nilbert, M.C., Su, L.K., Vogelstein, B., Brian, T.M., Levy, D.B., Smith, K.J., Preisinger, A.C., Hedge, P. and Mckechnie, D. (1991). Identification of FAP locus genes from chromosome 5q21. Science 253: 661-665.

Kuniyasu, H., Yasui, W., Yokozaki, H., Akagi, M., Akama, Y., Kitahara, K. Fujii, K. and Tahara, E. (1994). Frequent loss of heterozygosity of the long arm of chromosome 7 is closely associated with progression of human gastric carcinomas. Int. J. Cancer 59: 597-600.

Liu, B., Parsons, R., Papadopoulos, N., Nicolaides, N.C., Lynch, H.T., Watson, P., Jass, J.R., Dunlop, M., Wyllie, A., Peltomaki, P., De la Chapelle, A., Hamilton, S.R., Vogelstein, B. and Kinzler, K.W. (1996). Analysis of mismatch repair genes in hereditary non-polyposis colorectal cancer patients [see comments]. Nat. Med. 2: 169-174.

Maesawa, C., Tamura, G., Suzuki, Y., Ogasawara, S., Sakata, K., Kashiwaba, M. and Sadodate, R. (1995). The sequential accumulation of genetic alterations characteristic of the colorectal adeno-carcinoma sequence does not occur between gastric adenoma and adenocarcinoma [see comments]. J. Pathol. 176: 249-258.

Ministério da Saúde. Secretaria Nacional de Assistência à Saúde. Instituto Nacional de Câncer (INCA) (1998). Estimativa da Incidência e Mortalidade por Câncer no Brasil, 1998. INCA, Rio de Janeiro.

Mironov, N.M., Aguelon, M.A., Potapova, G.I., Omori, Y., Gorbunov, O.V., Klimenkov, A.A. and Yamasaki, H. (1994). Alterations of (ca)n DNA repeats and tumor suppressor genes in human gastric cancer. Cancer Res. 54: 41-44.

Miyaki, M., Konishi, M., Kikuchi-Yanoshita, R., Enomoto, M., Igari, T., Tanaka, K., Muraoka, M., Takahashi, H., Amada, Y. and Fukayama, M. (1994). Characteristics of somatic mutation of the adenomatous polyposis coli gene in colorectal tumors. Cancer Res. 54: 3011-3020.

Miyoshi, Y., Ando, H., Nagase, H., Nishiro, I., Horii, A., Miki, Y., Mori, T., Utsunomiya, J., Baba, S. and Peterson, G. (1992a). Germ-line mutations of the APC gene in 53 familial adenomatous polyposis patients. Proc Natl. Acad. Sci. USA 89: 4452-4456.

Miyoshi, Y., Nagase, H., Ando, H., Horri, A., Ichii, S., Nakatsuru, S., Aoki, T., Miki, Y., Mori, T. and Nakamura, Y. (1992b). Somatic mutations of the APC gene in colorectal tumors: mutations cluster region in the APC gene. Hum. Mol. Genet. 1: 229-233.

Nakatsuru, S., Yanagisawa, A., Ichii, S., Tahara, E., Kato, Y., Nakamura, Y. and Horii, A. (1992). Somatic mutation of the APC gene in gastric cancer: frequent mutations in very well differentiated adenocarcinoma and signet ring cell carcinoma. Hum. Mol. Genet. 1: 559-563.

Nakatsuru, S., Yanagisawa, A., Furukawa, Y., Ichii, S., Kato, Y., Nakamura Y. and Horii, A. (1993). Somatic mutations of the APC gene in precancerous lesion of the stomach. Hum. Mol. Genet. 2: 1463-1465.

Ogasawara, S., Maesawa, C., Tamura, G. and Satodate, R. (1994). Lack of mutations of the adenomatous polyposis coli gene in oesophageal and gastric carcinomas. Virchows Arch. 424: 607-611.

Park, J.B., Rhim, J.S., Park, S.C., Kimm, S.W., and Kraus, M.H. (1989). Amplification, overexpression, and rearrangement of the erB-2 proto- oncogene in primary human stomach carcinomas. Cancer Res. 49: 6605-6609.

Powell, S.M., Zilz, N., Beazer-Barclay, Y., Bryan, T.M., Hamilton, S.R., Thibodeau, S.N., Vogelstein, B. and Kinzler, K.W. (1992). APC mutations occur early during colorectal tumorigenesis. Nature 359: 235237.

Powell, S.M., Cummings, O.W., Mullen, J.A., Asghar, A., Fuga, G., Piva, P., Minacci, C., Megha, T., Tosi, P. and Jackson, C.E. (1996). Characterization of the APC gene in sporadic gastric adenocarcinomas. Oncogene 12: 1953-1959.

Rhyu, M.G., Park, W.S., Jung, Y.J., Choi, S.W. and Metzer, S.J. (1994a). Allelic deletions of MCC/APC and p53 are frequent late events in human gastric carcinogenesis. Gastroenterology 106: 1584-1588.

Rhyu, M.G., Parkm W.S. and Meltzer, S.J. (1994b). Microsatellite instability occurs frequently in human gastric carcinoma. Oncogene 9: 29-32.

Sanguinetti, C.J., Dias, N.E. and Simpson, A.J.G. (1994). Rapid silver staining and recovery of PCR products separated on polyacrylamide gels. Biotechniques 17: 914-921.

Sano, T., Tsujino, T., Yoshida, K., Nakayama, H., Haruma, K., Ito, H., Nakamura, Y., Kajiyama, G. and Tahara, E. (1991). Frequent loss of heterozygosity on chromosomes 1q, 5q, and 17p in human gastric carcinomas. Cancer Res. 51: 2926-2931.

Strickler, J.G., Zheng, J., Shu, Q., Burgart, L.J., Alberts, S.R. and Shibata, D. (1994). p53 mutations and microsatellite instability in sporadic gastric cancer: when guardians fail. Cancer Res. 54: 4750-4755.

Sud, R., Talbot, I.C. and Delhanty, J.D. (1996). Infrequent alterations of the APC and MCC genes in gastric cancer from British patients. Br. J. Cancer 74: 1104-1108.

Tahara, E. (1993). Molecular mechanism of stomach carcinogenesis [editorial]. J. Cancer Res. Clin. Oncol. 119: 265-272.

Tamura, G., Maesawa, C., Suzuki, Y., Ogasawara, S., Terashima, M., Saito, K. and Satodate, R. (1993). Primary gastric carcinoma cells frequently lose heterozygosity at the APC and MCC genetic loci. Jpn. J. Cancer Res. 8: 1015-1018.

Tamura, G., Maesawa, C., Suzuki, Y., Tamada, H., Satoh, M., Ogasawara, S., Kashiwaba, M. and Satodate, R. (1994). Mutations of the APC gene occur during early stages of gastric adenoma development. Cancer Res. 54: 1149-1151.

Uchino, S., Tsuda, H., Noguchi, M., Yokota, J., Terada, M., Saito, T., Kobayashi, M., Sugimura, T. and Hirohashi, S. (1992). Frequent loss of heterozygosity at the DCC locus in gastric cancer. Cancer Res. 52: 3099-3102.

Uchino, S., Noguchi, M., Ochiai, A., Saito, T., Kobayashi, M. and Hirohashi, S. (1993). p53 mutations in gastric cancer: a genetic model for carcinogenesis is common to gastric and colorectal cancer. Int. J. Cancer 54: 759-764.

Van der Luijt, R., Khan, P.M., Vasen, H., Van Leeuwen, C., Tops, C., Roest, P., Den Dunnen, J. and Fodde, R. (1994). Rapid detection of traslationterminating mutations at the adenomatous polyposis coli (APC) gene by direct protein truncation test. Genomics 20: 1-4.

Vogelstein, B., and Kinzler, K.W. (1993). The multistep nature cancer. Trends Genet. 9: 138-141.

(Received February 3, 2000) 
